\title{
西洋絵画に描かれた建築要素の二次元的な構成の認知評価の研究 STUDY ON EVALUATION OF COGNITION ON THE TWO-DIMENSIONAL REPRESENTATION OF ARCHITECTURAL ELEMENTS IN WESTERN PAINTINGS
}

\author{
松下希和*, 積田洋** \\ Kiwa MATSUSHITA and Hiroshi TSUMITA
}

\begin{abstract}
The objective of the research is to understand the cognition of the Western paintings, which represent three dimensional architecture and spaces in order to obtain the fundamental knowledge on the reception of twodimensional spatial representation. The Indication Method was used to quantitatively analyze the architectural and other elements in the paintings, their composition, and the impression they give to the viewers.

The research clarified the elements which characterize the paintings, including their categories and the degree of impression. The observation on their composition, moreover, showed the implication of the element structure and the spacial depth in the composition in two-dimensional representation in Western Paintings.
\end{abstract}

Keywords : Western Paintings, Evaluation of Cognition, Composition, Elements, Cofiguration of Elements, Type 西洋絵画, 認知評価, 構図, 構成要素, 要素の配置, 類型

\section{1. 研究背景 ·目的}

建築の二次元表現には、平面図や断面図などの他に三次元的な図 法があるが、その中でも透視図は建物がどのように見えるかを伝達 するプレゼンテーションの手段としてきわめて有効なものである。 Paul Kruty ${ }^{\text {i⿰1) }}$ のまとめを引用するとその伝達の受け取り手としては 1）建物の施主、2）展覧会の来館者、3）建築雑誌の読者があり、2）と3） は情報メディアが台頭した近代以降にその重要性が増した。現在で は CG も多く使われるようになったが、立体図法を応用した二次元表 現であることに変わりはない。さらに二次元的な空間の表現の中に は単体の建築を表現したものだけでなく、それが立地する環境や風 景との関係から空間を表現したものも含まれる。この場合には建築 は他の描かれたものと共に構成要素のひとつとなり、それらの相互 関係が「空間」を表現している。筆者らは透視画という二次元で表 現される建築、および建築空間が、様々な枠組みやスケール、構成 要素に応じて見る者にどのように認知されるかを明らかにする研究 を目指しているが、本稿はそのような枠組みの中で、特に広い範囲 を表現する西洋絵画のケースを分析しようとするものである。

立体図法による空間表現は主に西洋絵画で用いられ、発達した手法 である。E. パノフスキーは「〈象徴形式〉としての遠近法」 ${ }^{2)}$ で、ル ネサンス期に発明された幾何学的遠近法は、人間の眼が球状で常に
動いているという事実を捨象し、平らな面で空間を切断することに より、合理的で均質的な奥行きのある空間表現を可能にしたと述心 ている。つまり、このような形式化を通して、我々は実際の視知覚 とは少し異なる二次元的表現を空間の「正確」な表現として認識し ていることになる。また、何らかの焦点が設定される図法の形式か らだけでなく、前述のように、その形式上に描かれた構成要素によっ ても注視のされ方や空間の把握も違ってくると考えられる。

これらの理由から、本研究では二次元表現において建築やその他 の空間構成、及び要素とそれらの構成が人々に与える印象を定量的 に分析するために、空間認知の観点から印象評価実験法である指摘 法注2) を用いる。本稿では特に西洋絵画において、認知評価の高い要 素とその分布・配置の特徴から、人々が空間構成に対してもつ共通 のイメージがいかに形成されるかを明らかにすることにより、建築 の二次元的表現の認知に関する理解を深め、建築や空間表現の伝達 力に対する基礎的知見を得ることを目的とする。

\section{2. 既往研究の概要}

芸術学・美術史学の分野において、絵画と描かれている空間に関 しての研究は広く行われているが、都市・建築空間分野から西洋絵 画の空間について探った研究は比較的少ない。さまざまな遠近法を
* 東京電機大学未来科学部建築学科 准教授・修士 (建築学)

** 東京電機大学未来科学部建築学科 教授·博士 (工学)
Assoc. Prof., Dept. of Architecture, School of Science and Technology for Future, TDU,

M.Arch.

Prof., Dept. of Architecture, School of Science and Technology for Future, TDU, Dr. Eng. 
幾何学や視覚の観点から論じた黒田正巳の研究 ${ }^{3)} 、 15$ 世紀から 19 世 紀までの西洋絵画全般 ${ }^{4)}$ や、特定の地域 ${ }^{5)}$ や作家 ${ }^{6)}$ を対象として、 描かれているジャンルや構成要素と距離や面積について分析した若 山滋らの一連の研究がある。また、建築空間の 2 次元表現に関しては、 実際の建物と西洋絵画に描かれた透視画の空間特性の相違点を探っ た福留吉絵らの研究 ${ }^{7)}$ やF.L. ライトの住宅の透視図を分析し類型化 した坪山幸王らの研究 ${ }^{8)}$ がある。本研究は、主として絵画的表現技 法そのものを扱った上記の諸研究とは視点が異なり、絵画の構成要 素と見る人に与える印象評価を数量的に扱ったところに特色がある。

これまで筆者らは実際の建築・都市空間を対象にした指摘量分析 や認知特性の研究 ${ }^{91}{ }^{10)}$ のみならず、言語などで表現された空間を対

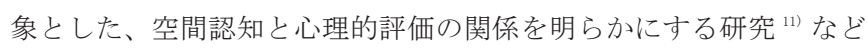
も行ってきた。本研究は、これらの研究手法を用いて、西洋絵画に 描かれた建築空間と、建築やその他の構成要素によって表現される 空間を対象に、人々の建築の二次元的表現の認知のあり様について 分析する。

\section{3. 分析対象絵画の選定と実験概要}

分析対象の選定にあたっては、米国と日本の高等教育で西洋美術 史の教科書として長く定評がある書籍、『Janson's History of Art: Western Tradition』の 8 版 $^{12)}$ 、『Gardner's Art Through Ages』の 12 版 ${ }^{13}$ 、『カラー版 西洋美術史』 ${ }^{14)}$ 、そして『高校美術 1・2』 ${ }^{15)}$ に 掲載されている絵画のうち、幾何学的遠近法が確立したルネッサン スから近代までの間で建築物が描きこまれた全ての具象画を、一旦 抽出した。内部空間も重要な建築の空間であるが、外観と内部空間 では表現されている空間の性質が異なるため、同一の実験では評価 が困難である。したがって、本稿では建築を他の描かれたものと同 様に空間を構成する視覚要素として扱うこととし、外観が描かれて いる絵画に分析対象を絞った。建物の外観は、一部分がクローズアッ プされているものや、遠景に群として描かれているものなど、さま ざまなケースが含まれる。宗教画は特有の象徵体系があるため対象 から外し、本研究が最終的に目指寸設計図面の表現との関連を考慮 して、絵画のサイズはB0（1030X1456 mm）以内とした。また、個別 の画家に偏らないように、一画家あたり一作品としたところ、分析 の対象絵画数は 39 点となった。(図 1,4)。

実験の方法としては、対象絵画の画像を高解像度注3) で原寸大に出 力し、絵の中央が床から $1.5 \mathrm{~m}$ の高さになるよう壁に掲示して、建築 学科と建築・デザイン学科の学生 50 名 (男性 22 名、女性 28 名) ${ }^{\text {(i4) }}$ ) に、 絵画のタイトルや画家の名前などを伝えずに、それぞれの絵画の対 角線の 2 倍の距離から観覽してもらった（図 2)。指摘法により強い 印象を与える要素を最低 3 つ以上、最大 5 つまで挙げさせて、絵画 ごとに配布した実験用紙の画像上にその位置を布置してもらい、そ れらの強弱を 5 段階で評価してもらった注)。

\section{4. 指摘法分析}

\section{1 ）全体傾向}

研究目的で述べたように、空間の構成要素によって注視のされ方 が異なると推測されるので、各絵画において、印象が強く指摘され た要素 (指摘要素) を集計した。なお、できるだけ被験者の挙げた 項目のまま種別を行い、たとえば人物など「男女」や「子供たち」
日米の高校 · 大学で使われる代表的な美術史の教科書 5 冊より三次元 的な空間表現が確立した 15 世紀後半から 20 世紀までの絵画を抽出。 413 点

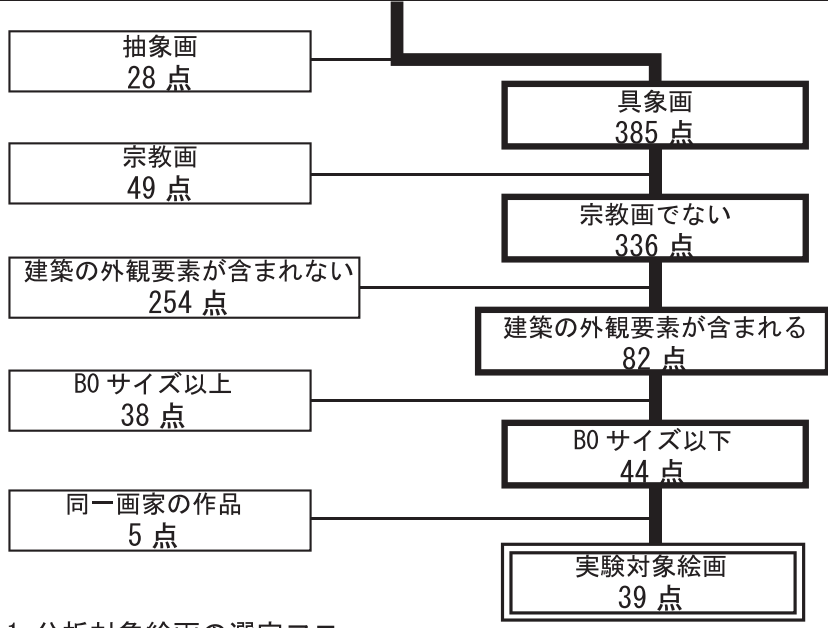

図 1 分析対象絵画の選定フロー

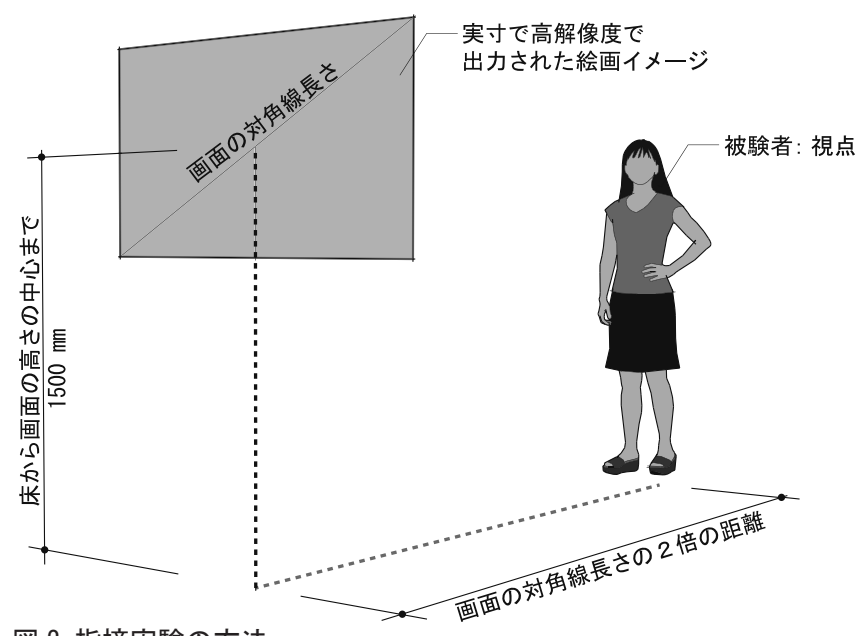

図 2 指摘実験の方法

表 1 要素別指摘率の男女差

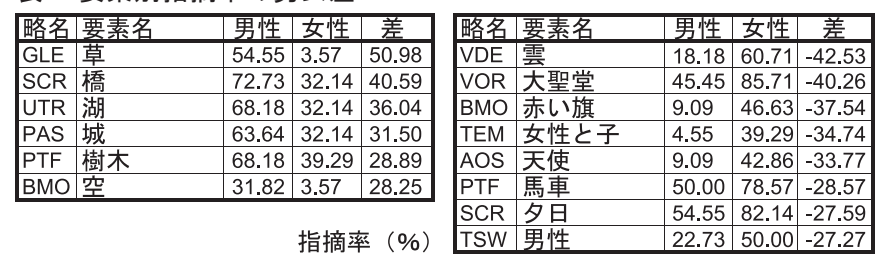

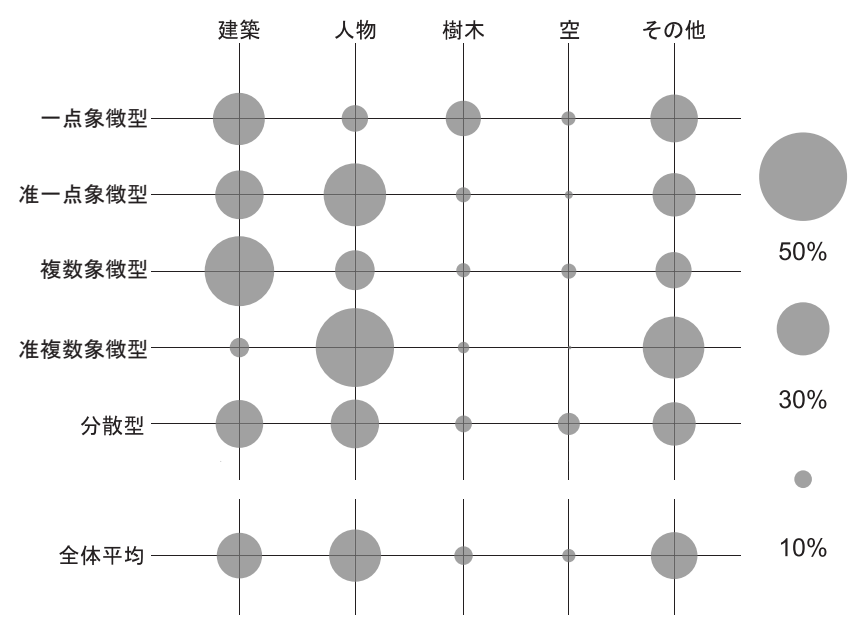

図 3 タイプ別指摘要素のカテゴリー分類 


\begin{tabular}{|c|c|c|c|c|c|c|c|c|c|c|c|}
\hline \multirow{3}{*}{ タイトル } & \multirow{3}{*}{ 略名 } & \multirow{3}{*}{ 画家名 } & \multirow{3}{*}{ 年 } & \multirow{3}{*}{ タイプ } & \multirow{3}{*}{\begin{tabular}{|c|} 
最高 \\
指摘 \\
率
\end{tabular}} & \multicolumn{6}{|c|}{ 被験者からの距離 $\quad \square \cdots$ 主題、 $\diamond \cdots \cdots$ 背景 } \\
\hline & & & & & & 至近距離 & 近空間 I & 近空間 II & 中空間 I & 中空間 II & 遠空間 \\
\hline & & & & & & $2-10 m$ & $10-25 \mathrm{~m}$ & $25-60 \mathrm{~m}$ & $60-500 \mathrm{~m}$ & $500 \mathrm{~m}-1 \mathrm{~km}$ & $1 \mathrm{~km}-$ \\
\hline Pelkus Gate near Utrecht & UTR & Jan van Goyen & 1646 & \multirow{8}{*}{$\begin{array}{l}\text { 一点象 } \\
\text { 徽 型 } \\
(40 \% \\
\text { 以上) }\end{array}$} & $98 \%$ & & & & & 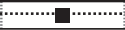 & $\ldots \cdots \cdots$ \\
\hline Bleaching grounds near Haarlen & HAA & Jacob van Ruisdael & 1670 & & $94 \%$ & & & & & ............ & $\cdots \cdots \cdots$ \\
\hline The Swing & TSW & J.-H. Fragonard & 1767 & & $98 \%$ & & $\mathbf{E \cdots}$ & & $\cdots \cdots$ & & \\
\hline The House at Rueil & $\mathrm{HRU}$ & Edouard Manet & 1882 & & $96 \%$ & & $\cdots \cdot$. & $\cdots \cdots$ & & & \\
\hline Mont Sainte Victoire & MSV & Paul Cezanne & 1887 & & $100 \%$ & & & & $\cdots \cdot$ & (n............. & $\cdots \cdots \cdots$ \\
\hline Landscape with Red Trees & LRE & Maurice de Vlaminck & 1907 & & $90 \%$ & & & E.... & $\cdots \cdots$ & & \\
\hline Kizette in Pink & KIP & Tamara de Lempicka & 1926 & & $92 \%$ & $\mathbf{E} \cdot$ & ...... & & $\cdots \bowtie$ & & \\
\hline Early Sunday Morning & ESM & Edward Hopper & 1930 & & $90 \%$ & & & $\bar{\square} \diamond$ & & & \\
\hline The Blind Leading the Blind & BLB & \begin{tabular}{|l} 
P. Bruegel the Elder \\
\end{tabular} & 1568 & \multirow{7}{*}{$\begin{array}{l}\text { 准一点 } \\
\text { 象徵型 } \\
\text { (40\% } \\
\text { 未満、 } \\
25 \% \text { 以 } \\
\text { 上) }\end{array}$} & $70 \%$ & & $\mathbf{E \cdots}$ & & & & $\triangleright$ \\
\hline Cornelia Presenting Her Children & CPC & Angelica Kauffmann & 1785 & & $88 \%$ & & $\overline{n+\cdots}$ & & & & $\diamond$ \\
\hline On the Bank of the Seine & SEI & Claude Monet & 1868 & & $90 \%$ & & 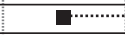 & & 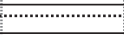 & & $\cdots \cdots$ \\
\hline Gray Weather, Grande Jatte & GWG & Georges Seurat & 1888 & & $92 \%$ & & & $\bar{m} \cdot$ & 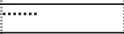 & & $\cdots \cdots$ \\
\hline Sixth Avenue and $30^{\text {th }}$ Street & SAS & John Sloan & 1909 & & $92 \%$ & & 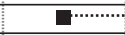 & 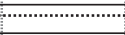 & $\cdots \cdot$ & & $\cdots \cdots$ \\
\hline Snap the Whip & STW & Winslow Homer & 1872 & & $86 \%$ & & E............... & 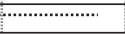 & & ....... & $\cdots \cdots$ \\
\hline My Egypt & MEG & Charles Demuth & 1927 & & $84 \%$ & & $\mathbf{E} \cdots \cdots \cdots$ & $\cdots \cdots$ & & & \\
\hline Old Man and Death & OMD & Joseph Wright & 1773 & \multirow{4}{*}{$\begin{array}{l}\text { 複数象 } \\
\text { 徵 型 } \\
\text { ( } 40 \% \\
\text { 以上) }\end{array}$} & $96 \%$ & & E............... & & & $\diamond$ & \\
\hline View of Rome & VOR & Camille Corot & 1827 & & $76 \%$ & & & $\cdots .$. & ………… & & $\cdots \cdots$ \\
\hline Villa R & VIR & Paul Klee & 1919 & & $92 \%$ & & 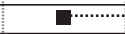 & $\cdots .$. & $\ldots \ldots \ldots \ldots$ & $\cdots \cdots$ & \\
\hline Christina's World & CHW & Andrew Wyeth & 1948 & & $100 \%$ & & 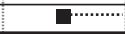 & & & $\cdots \cdots$ & \\
\hline The Judgment of Paris & JOP & L. Cranach the Elder & 1528 & \multirow{8}{*}{$\begin{array}{l}\text { 准複数 } \\
\text { 象徵型 } \\
(40 \% \\
\text { 未満 } \\
25 \% \text { 以 } \\
\text { 上) }\end{array}$} & $76 \%$ & & $\mathbf{E} \cdot$ & & & & $\cdots \cdots$ \\
\hline Mezzetin & MEZ & J.-A. Watteau & 1718 & & $88 \%$ & & E..... & $\cdots \cdots$ & & & \\
\hline Soap Bubbles & SBB & Jean Chardin & 1733 & & $92 \%$ & $\mathbf{D} \diamond$ & & & & & \\
\hline Beata Beatrix & BEB & D. G. Rossetti & 1870 & & $74 \%$ & (E...... & $\cdots \cdots \cdots \cdot \cdot \cdot \cdot$ & $\cdots \cdots$ & $\diamond$ & & \\
\hline Villa at the Seaside & VSE & Berthe Morisot & 1874 & & $86 \%$ & & 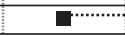 & 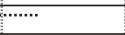 & & & $\cdots \cdots$ \\
\hline The Harvest & THA & Vincent van Gogh & 1888 & & $68 \%$ & & & $\bar{m} \cdot$ & $\ldots \ldots \ldots$ & $\ldots \ldots \ldots$ & $\cdots \cdots$ \\
\hline Mystery and Melancholy of a Street & MMS & Giorgio de Chirico & 1914 & & $88 \%$ & & & E.... & 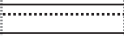 & $\cdots \cdots$ & $\cdots \cdots$ \\
\hline American Gothic & AGO & Grant Wood & 1930 & & $68 \%$ & 口 & & $\cdots \cdots \cdots$ & & & \\
\hline The Tempest & TEM & Giorgione & 1510 & \multirow{12}{*}{$\begin{array}{c}\text { 分散型 } \\
(25 \% \\
\text { 未満) }\end{array}$} & $68 \%$ & & 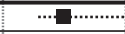 & 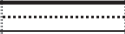 & 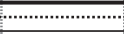 & $\cdots \cdots \cdots$ & \\
\hline Allegory of Sight & $\mathrm{AOS}$ & J.Brueghel, P.Rubens & 1617 & & $62 \%$ & & E.............. & & & & $\cdots \cdots$ \\
\hline A Pastoral Landscape & PAS & Claude Lorrain & 1648 & & $70 \%$ & & & & $\cdots \cdots \cdot \cdots$ & $\ldots \ldots$ & $\cdots \cdots$ \\
\hline View of Delft & VDE & Johannes Vermeer & 1661 & & $54 \%$ & & & & …......... & $n+\cdots \cdots$ & $\cdots \cdots$ \\
\hline Avenue at Middelharnis & $\mathrm{AMH}$ & Meindert Hobbema & 1689 & & $50 \%$ & & & $\mathbf{E} \cdots$ & (n).................... & $\cdots \cdots$ & $\cdots \cdots$ \\
\hline The Bucintoro at the Molo & BMO & Canaletto & 1732 & & $76 \%$ & & & $\cdots \cdot \cdot$ & 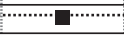 & a................ & $\cdots \cdots$ \\
\hline The Gleaners & GLE & Jean Francois Millet & 1857 & & $54 \%$ & & $\mathbf{E \cdots \cdot \cdot}$ & & & ....... & 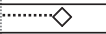 \\
\hline Max Schmitt in a Single Scull & MAX & Thomas Eakins & 1871 & & $80 \%$ & & ……... & & 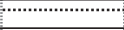 & $\cdots \cdots \cdots$ & \\
\hline The Sacred Grove & GRO & Puvis de Chavannes & 1884 & & $74 \%$ & & & 口........... & 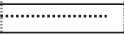 & & $\diamond$ \\
\hline The Scream & SCR & Edvard Munch & 1893 & & $88 \%$ & & 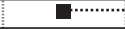 & & ……... & & $\bullet \diamond$ \\
\hline La Place du Thetre Francais & PTF & Camille Pisarro & 1898 & & $66 \%$ & & & & E* & $\cdots \cdots$ & \\
\hline New York, Night & NYN & Geogia O'Keeffe & 1929 & & $64 \%$ & & & & & $\bar{E}$ & $\cdots \cdots$ \\
\hline
\end{tabular}

\section{図 4 分析対象絵画リストと描かれた要素との距離}

のように、群として指摘された要素は、その構成要素を個別にわけ てしまわず、別項目として扱った。1枚の絵画に対して最少 10 個 【CHW】、最大 26 個【CPC】、平均で 17.90 個の要素が挙げられた。指 摘要素の中で 50 人のうち 6 人以上が指摘した要素（12\%以上 $\left.{ }^{\text {i:6) }}\right)$ を その絵画の主要素と定義した。その数は平均 7.4 個で、標準偏差は 1.57 とばらつきは少なかった。主要素を「建築」「人物」「樹木」「空」 注7) と、それ以外の「馬」や「サインポール」のように共通項に含め られない要素を「その他」注8) に分類し、この 5 つのカテゴリーの指 摘数に比例させた円を絵画上にプロットし、ドットマップ図を作成 (図 5)、分析を行った。

また、5つのカテゴリーに分類した指摘要素について、指摘数を被 験者数 50 で割ることで指摘率を算定した。平均の指摘率の多い順は 「人物」「その他」「建物」「樹木」「空」となった。「人物」の要素が 含まれた 30 点の絵画において、「人物」の指摘は総指摘数の $38.19 \%$ を占め、画面に占める面積が少ない場合でも、人物が強く認識され ていることが明らかになった。

\section{2 ) 性別による指摘要素の差異}

男・女の性別ごとに指摘率を比較すると、一部の印象の強い指摘 要素に異なる傾向が見られた。有意水準 $5 \%$ として p 值を計算したと ころ、39 点の絵画のうち、男女で有意差が表れたものは 14 点あった (表 1)。指摘要素の性別による特徵を見ると、男性は女性より「樹 木」のような自然要素に指摘が多かった。それらのうち、特に「草原」 や「湖」など一つの物体として認識されるものでなく、通常背景と
思われる環境要素洋9 において男性の指摘数は顕著であった。一方、 女性の指摘要素の特徴として、「女性と子供」や「男性」のように人物、 特に子供に着目したものが挙げられる。また、人物以外の指摘要素も、 大半は物体として特定できる要素であった。

このような男女の差は見られるのの、性差を得ることが必ずしも 主眼ではないことと、ほぼ同数の男女の被験者数であることもあり、 以下の分析では全体的な傾向を見るために一括して進めることとし た。

\section{5. 象徵的要素の構成の分析}

絵画を特徴づける要素の構成を明らかにするため、絵画毎に指摘 要素の指摘率のグラフを作成し、それを低減傾向によって 5 タイプ に類型化した（図 4,5)。〈一点象敷型〉は、その絵画を特徴づける 指摘率がきわめて高い要素がひとつあるタイプで、最も多く指摘さ れた要素と次点との差が $40 \%$ 以上、〈准一点象徵型〉は $40 \%$ 未満、 $25 \%$ 以上した。指摘率の高い要素が複数あり、指摘率上位の要素 と下位の要素の指摘率に $40 \%$ 以上の差があるものを〈複数象徵型〉、 $40 \%$ 未満、 $25 \%$ 以上のものを〈准複数象徵型〉とする。指摘率の差 があまりないものを〈分散型〉とした。各タイプの絵画の制作年に は偏りがなく、描かれた様式と印象の強い要素の構成とは直接関連 が見られなかった。

また、見る者の空間認知と個々の絵画のもつ二次元空間の奥行き の広がりなどの関係を見るため、画面の奥行きと指摘の傾向との関 
係を分析した。具体的には、絵画のタイトルなどから推測される画 家が意図した主題や背景と被験者との間の距離を、描かれている要 素の大きさや細かさから 6 段階に推定し ${ }^{\text {10) }}$ 、タイプごとに分類した (図 4)。また、タイプごとに指摘要素を前出の 5 つのカテゴリーに分 類し、それらの指摘率の平均值に対応した大きさの円で表した (図 3)。 以下に各タイプの特徵を述べる。

〈一点象徵型〉に分類された 8 点の絵画のうち、【TSW】と【KIP】以外は、 主に風景が描かれており、人物は描かれていないか存在感が薄い特 徵がある。カテゴリー別に見ても「建築」がもっとも高く、「その他」「樹 木」と続き、「人物」は 4 番目になっている。最高指摘率は総じて高 い。被験者から主題との距離は〔至近距離〕から〔中間空間 II ま で様々だが、それらと背景との距離が短く、比較的奥行きを感じさ せないもの、また情景が被験者から遠くに描かれているものが多い。 指摘数の平均は 17 個と標準的だが、画面の奥行きが限られるため、 目立って認識される要素が集中してしまうと考えられる。一方、7 点 ある〈准一点象徵型〉は【GWG】と药可以外は人物の存在感が高い。 〔近空間〕に群像が描かれており、そこから深い奥行を感じさせるも のが多い。カテゴリー別に見ても「人物」が一番指摘を受けていたが、 最高指摘率の要素は人物でないケースが多い。複数の人物が描かれ ている場合、指摘が何人かに分散してしまい、〈一点象徵型〉のよう
に特定の対象に集中しなかったと考えられる。〈複数象徴型〉は 4 点 あり、指摘数上位の要素が 3,4 個あるものが多かった。指摘要素の カテゴリー別に見ると〈一点象徴型〉と同様に「建築」が最も高かっ たが、次点は「人物」だった。被験者が建築の学生であることの影 響は考え得るが、画家によって建築物が焦点要素として取り上げら れる傾向が強いと考えて良いと思われる。ほとんどの主題は〔近空 間】にあり、背後に奥行を感じさせるものが多い。〈複数象徵型〉の み指摘数平均が 11 、主要要素数が 4.75 と平均より明らかに少なかっ た。ほとんどの被験者が指摘数上位のいくつかの要素に着目し、他 の要素は印象に残らなかったと推測される。 8 点ある〈准複数象徴型〉 は「人物」カテゴリーの指摘率が非常に高く、「建築」が低い。対象 絵画の中で、人物が〔至近距離〕に配された構図の 4 点のうち 3 点 が〈准複数象徴型〉に入っている。その場合は人物が詳細に描かれ ているため、顔や身体のパーツが個別に認識されていると思われる。 〈分散型〉は最も多く、12 点あった。指摘要素のカテゴリーは分析対 象絵画の平均值に類似しており、「人物」が最も高いものの、「建築」 や「その他」との差は少なく、各カテゴリーに分散している。〈点 象徴型〉と同様に風景画が多いが、情景が〔近空間 II から〔中空 間〕まで被験者から遠い距離に描かれているため視野が広がる一方、 ひときわ象徴性の強い要素が無いことで、印象に残る要素が人によっ

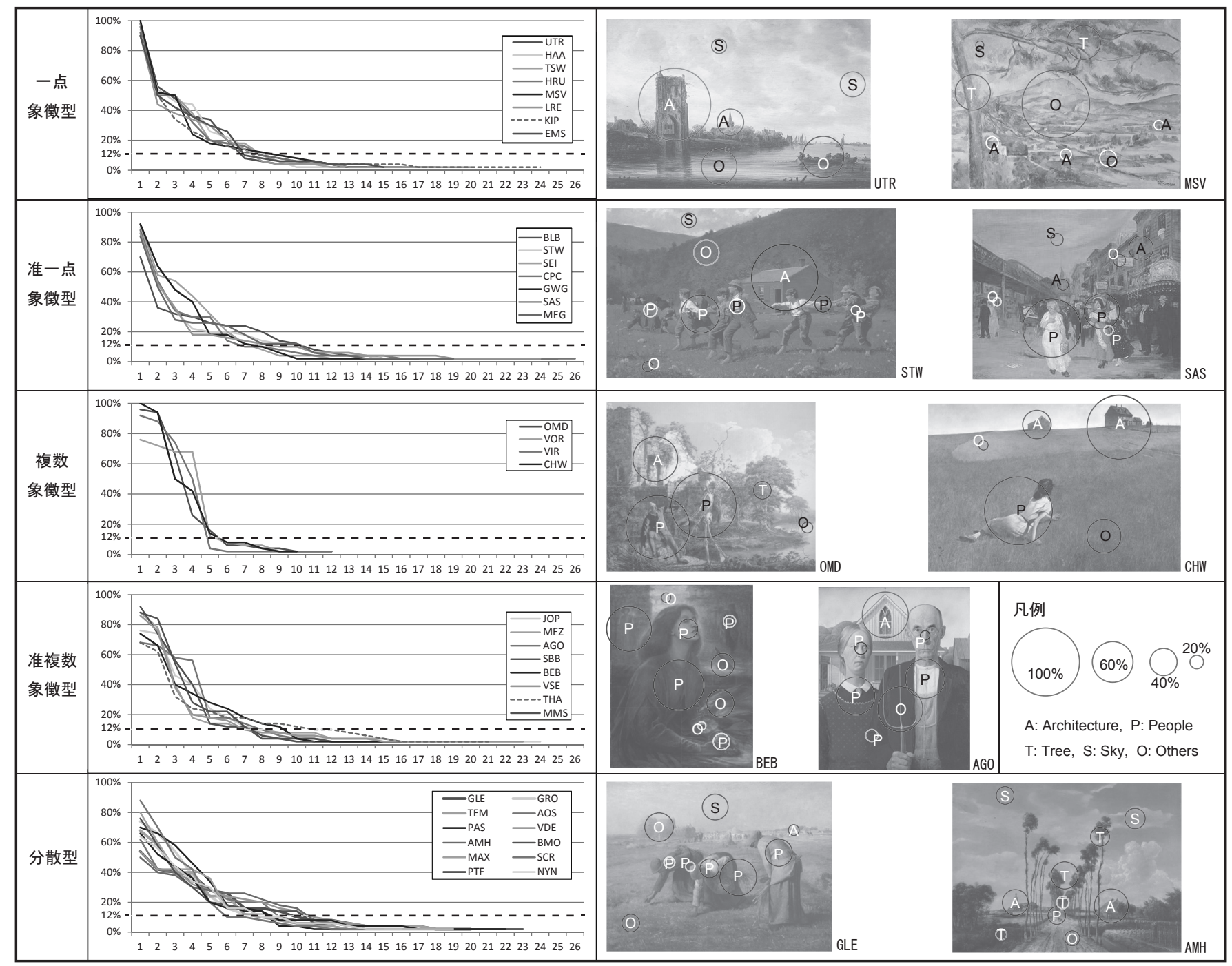

図 5 指摘要素の低減傾向による類型化と各タイプの特徵的な例 
て異なっていると推測できる。

\section{6. 指摘要素と構図の分析}

\section{1 ) 指摘要素の構成型と注目域の概要}

指摘されや寸い要素の特徵とそれらの構成を捉えるため、指摘要 素のカテゴリー別の分類を行った。各絵画ごとに要素を前出の「建築」 「人物」「樹木」「空」「その他」の 5 つのカテゴリーに分類し、それ ぞれの要素数を類似度としてクラスター分析 (最遠距離法) ${ }^{\text {i土 }} 11$ を行っ た（図 6)。それぞれの指摘要素の構成を見るため、5つのカテゴリー ごとに指摘率の平均値を対応した大きさの円で表した（図 7)。その 結果、「樹木と建築」、「建築」、「その他」、「人物」カテゴリーの指摘 要素が多い 4 タイプに類型化し、それぞれ〈樹木と建築要素構成型〉、 〈建築要素構成型〉、〈之の他要素構成型〉、〈人物要素構成型〉と定義 した。もっとも数が多いのは〈人物要素構成型〉で、18 点あり、他 の要素に比べて「人物」への指摘の集中が明確だった。〈建築要素構 成型〉では通常印象の強い「人物」への指摘が際立って低く、また 樹木一の指摘も低い代わりに「空」の指摘が多いことが特徵的である。

一方、絵画の中で指摘が集中する注目域の特徴を明らかにするた

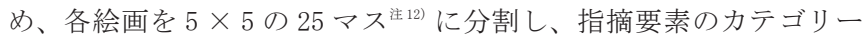
は問わずに、位置するマスにその指摘数をプロットし、集計した。 これを類似度としてクラスター分析（最遠距離法）を行い、6タイプ に分類（図 8）した。また、分析対象絵画全部の平均とタイプごとの 指摘数の平均の分布を 25 マスにグラデーションの濃淡で表した（図 9)。このグリッド解析図 ${ }^{\circledR 13)}$ から全体の平均としては、中央のマスと、 その上下左右に指摘が集中していることがわかる。クラスター分析

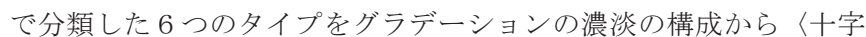
形型〉〈右下分布型〉〈左下分布型〉〈三角形型〉〈上部分布型〉〈中央 分布型〉と呼ぶ。

\section{2 )「仮面の主題」の定義}

指摘率が高い要素の中には、印象に残る要素として挙げられなが らも、印象の強弱を問う 5 段階評価（指摘度）は高くないものがある。 それらを抽出するため、各指摘要素の指摘率と指摘度数率（指摘度 数の総和 /最高度数 $5 \times$ 被験者数 50）との差を算出し、第一指摘要 素と第二指摘要素の中で差異が $25 \%$ 以上あるものを要素別タイプに 分けてプロットした（図 12）。

指摘率と指摘度数の差異の大きい要素は、描かれている場面の中 の重要度は低く、「主役」と認識されないが、絵画を特徴づける印象 を与えるものといえる。これを「仮面の主題蕉14」と呼ぶ。仮面の主 題のカテゴリーを見ると、2 5 点中 10 点が「建築」要素であった。

ゲシュタルト心理学で言うところの「図」と「地」を当てはめると、 今回の実験の指摘率の平均は人物が高く、樹木や空は低いことから、 人物が「図」、空、樹木などは「地」と捉えられていると考えられる。 一方、指摘率の平均が人物やその他の要素に次いで高い建築は描か れ方によって「図」か「地」、または「主役でないのに主役並に注目 を集める図的な地」(仮面の主題) と認識されていると考えられる。

要素構成型別に各絵画において建物が「主役」か「背景」かで質 問した結果を集計し（図 10）比較したところ〈建築構成型〉のみ $3 / 4$ の人が建築が「主役」と返答し、それ以外のタイプでは「背景」 と答えた率が高かった。このことからも、人物や樹木の存在感が強 い絵画で「建築」が指摘されている時は「仮面の主題」になり、そ

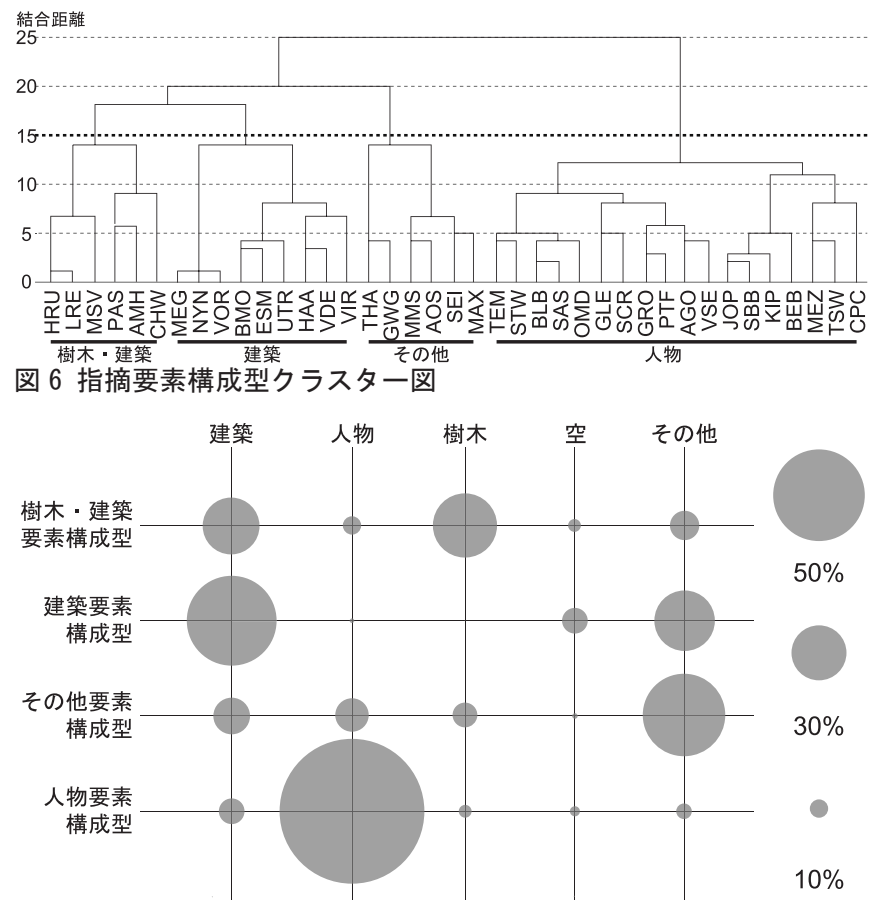

図 7 指摘要素構成型タイプ

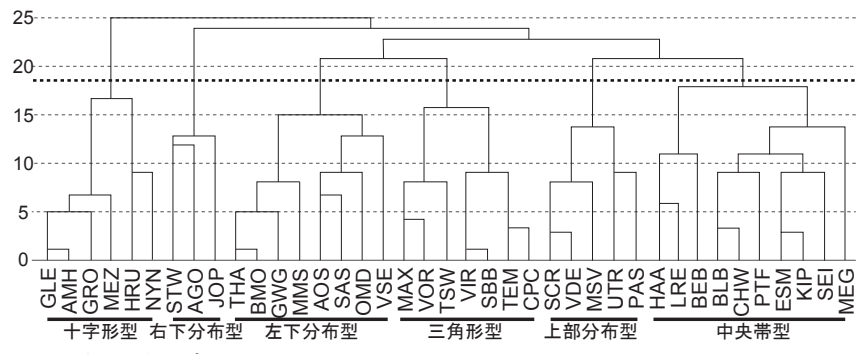

図 8 注目域分布型クラスター図

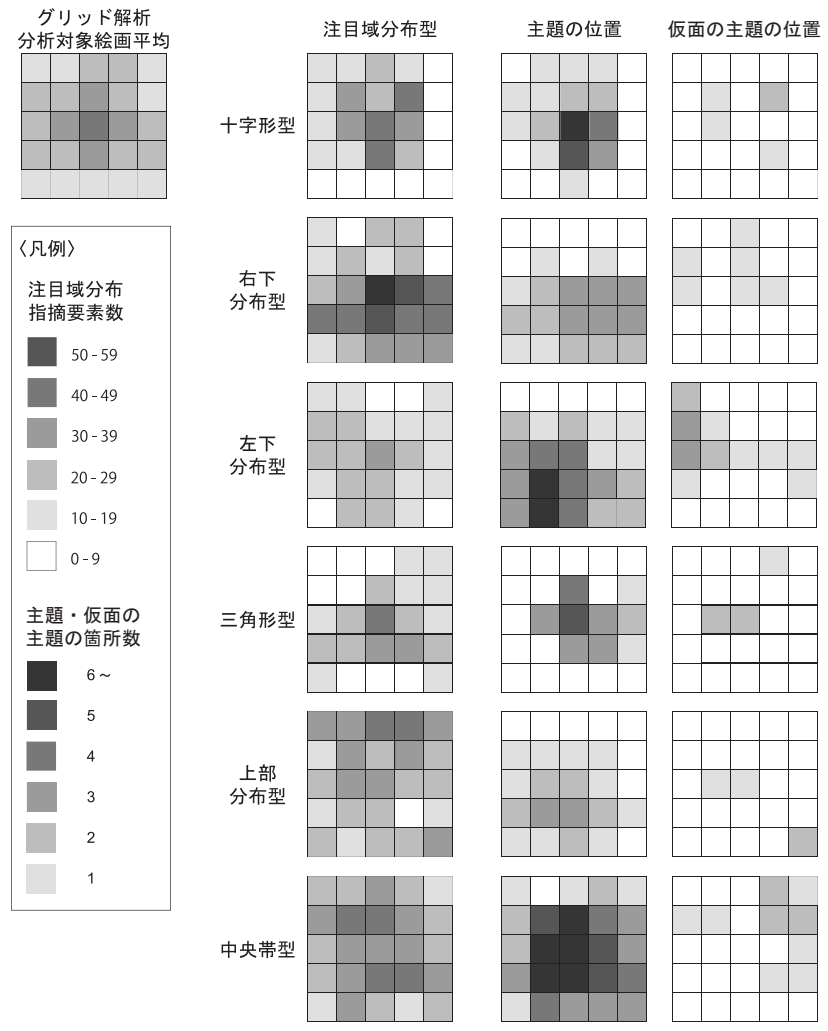

図 9 注目域分布型タイプと主題と仮面の主題の位置 
れらの要素が不在、または印象に残らない絵画では「主題」と認識 されることがわかる。

仮面の主題が建築要素であるものは〈樹木・建築構成型〉と〈人 物構成型〉に見られ、多くが本来の主題の背後の〔中空間〕にある 単体の建築だった。例えば、【BLB】は「The Blind Leading the Blind」 のタイトルの通り、画面手前に大きく描かれている人物群が主役で あるが、その奥にある教会が最も指摘を受けた（図 11）。一方、建築 が「主役」と認知されている〈建築構成型〉では建築要素は群で街 を形成しているか、被験者から近い距離に正対して大きく描かれた 構図が多い。その場合は【ESM】のように、仮面の主題は建築要素以 外のもの（サインポール）で、主役より手前に配置されている場合 もある（図 11）。

仮面の主題と主題の構図上の関係を分析するため、それぞれの位 置を 25 マスにプロットした（図 9)。主題はほとんどが中心部付近に 描かれているが、仮面の主題は周縁部に位置するものが多く、絵画 の主題と離れた構成で描かれていることもある。これはアイストッ プのように視線を画面から離さず、主題に戻すことで「主役」引き 立たせ、絵画の構図の上で特徴を生む役割を果たしていることが推 測される。

一方、全分析対象絵画 39 点のうち、「仮面の主題」を持たない 14 点は指摘される要素の指摘率と指摘度が比例しているもので、本来 の主題が認知されやすく表現されていると言える。9 点が〈人物要素 構成型〉だった。人物は全般に指摘率が高く、絵の中の「主役」と 認識されることが多いが、これらの9 点はその中でも、認知のヒエ ラルキーが明解に表されていると言える。

\section{3) 指摘要素と構図の分析}

要素構成型と注目域分布型について、両者のタイプごとの相互関 係をマトリックス表に表し（表 2)、どのような指摘要素で構成され た絵画で、どの位置が着目されているかの傾向を分析した。同表に は「仮面の主題」の有無も示した。また、絵画を参考文献 14）によ る 5 つの様式区分 ${ }^{(14)}$ に分類し、構図と描かれた様式や時代背景との 関連を考察した。分析結果の傾向を以下に述べる。

左右対称に近く縦方向の構図が特徵的な〈十字形型〉は、〈その他 要素構成型〉以外のカテゴリー型で見られる。絵画ごとの特徵を見 ると【AMH】(樹木・建築要素構成型) や【NYN】(建築要素構成型) など特に垂直性の高い要素が印象的なものが含まれている。主題の 位置からも中心性の高い構図であり「仮面の主題」を持たない絵画
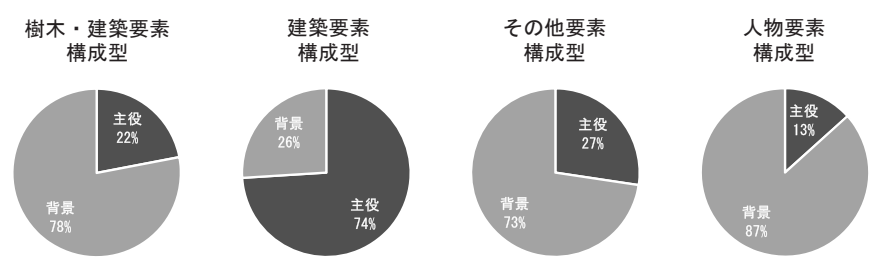

図 10 「主役」「背景」の割合

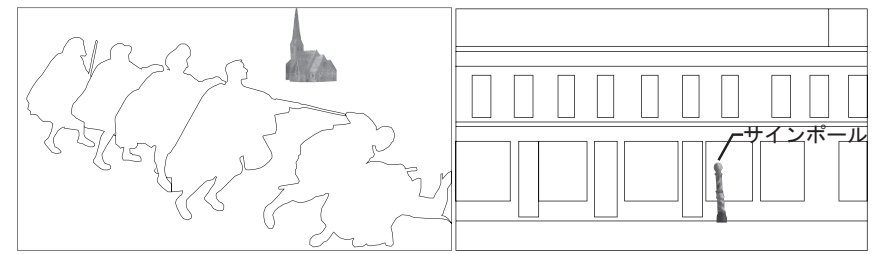

図 11 仮面焦点の例 【BLB・左】【ESM・右】

表 2 要素構成型と注目域分布型

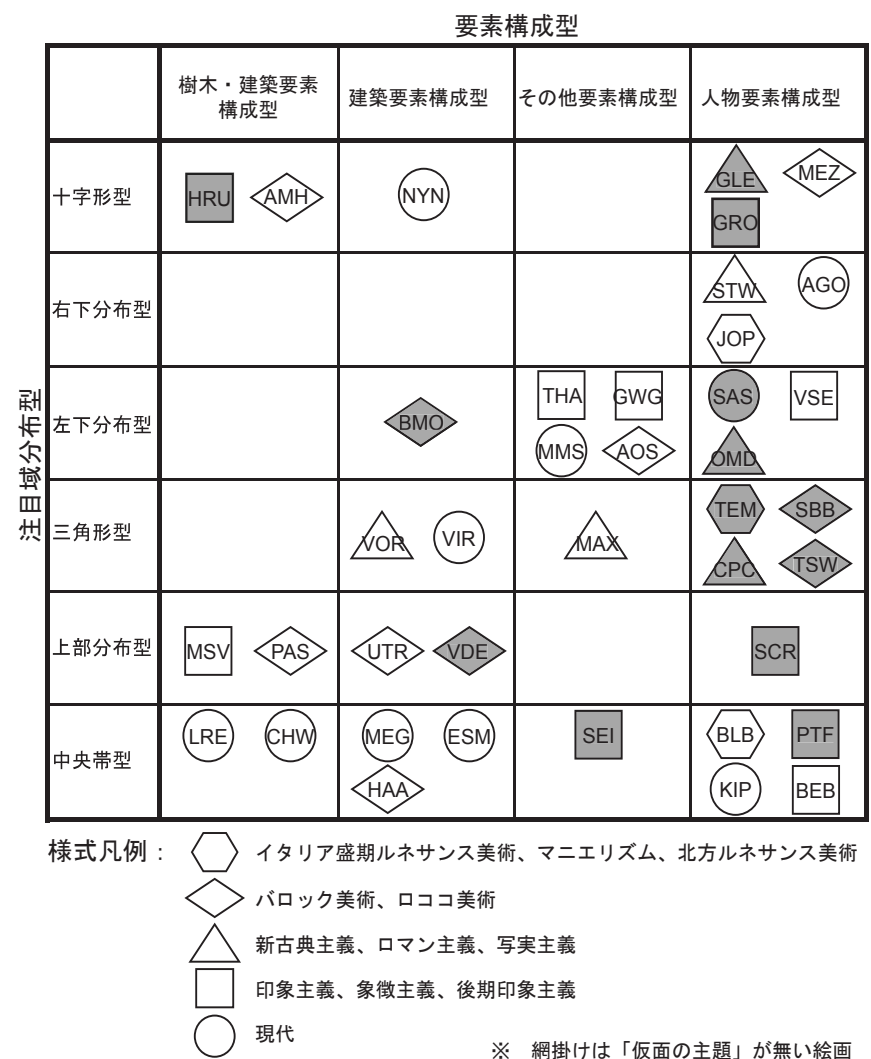

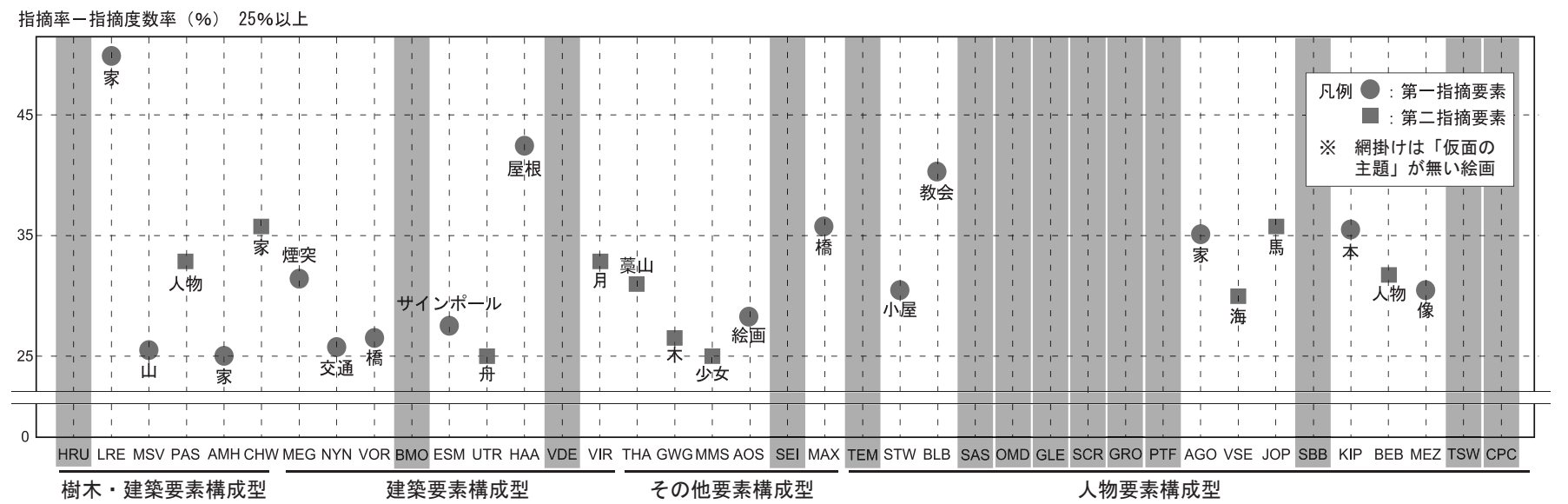

図 12 指摘率と指摘度数率の差異 
が 6 点中 3 点あることからも、比較的主題を捉えやすい構図と言える。 印象の強い要素が主に中央から右下にかけて分布している〈右下分 布型〉は 3 点すべてが〈人物要素構成型〉であった。それぞれ複数 の人物が画面の左端から右端まで描かれているが、人物の大きさな どから印象の重心は中心から右に寄っていることがわかる。複数の 人物の中の「主役」が明解でないため、「家」や「馬」のような「仮 面の主題」に指摘が集まっている。〈左下分布型〉は 8 点あり、その うち〈その他要素構成型〉が 4 点あるが、全般に指摘数が少なく、 際立って印象的な要素がほとんどない。〈十字形型〉、〈右下分布型〉、 〈左下分布型〉にはルネサンス美術から現代までの絵画が特に偏りな く含まれており、特定の様式との関連は見られなかった。一方、〈三 角形型〉はグリッドの中心に主題が配置された安定した三角形型の 構図タイプで、7 点中 4 点が〈人物要素構成型〉で群像が描かれたも のである。しかし、〈右下分布型〉と異なり、4 点すべてに「仮面の 主題」が無いことからも、中央の人物を頂点とした認知のヒエラル キーがはっきりとした構図と言える。さらに、絵画の描かれた年代 や様式を見ると、18 世紀から 19 世紀のロココから新古典主義の様式 の絵が多かった。〈上部分布型〉は実際の主題の位置は中央より下に 多く分布しているが、画面のほとんど全域に指摘要素が分布し、特 に上部に重心が集まっているタイプである。〈人物構成型〉の【SCR】 以外の 4 点は主に風景を描いた絵であり、雲が特徴的で「空」が比 較的強い印象の絵画が多い。今回の結果では〈上部分布型〉の絵画 はバロック美術と後期印象主義の様式であったが、この場合は様式 より風景画である共通点の影響が大きかったと推測される。〈中央帯 型〉は画面全域に指摘要素が分布しているが、二、三、四段目の行 のマス (中心帯) に比較的重心が集まっている水平性が強い構図で あり、10点がこのタイプである。全ての要素構成型に見られるが、健 築要素〉と〈人物要素〉構成型が多い。「仮面の主題」を持つ絵は 10 点中 8 点と多く、指摘要素が広範囲に分布しており、一見絵画の主 題がわかりにくい構図と考えられる。

時代様式の観点からは、今回の実験で「仮面の主題」を持つ割合 がもっとも大きかったのは 20 世紀以降の現代絵画であり、10 点のう ち、9 点に「仮面の主題」が見られ、そのうちの 5 点が〈中央帯分布型〉 であった。柳亮によると、絵画史を通じて発展してきた黄金分割構 図法を基にした構図法は、近代に入り急速に顧みられなくなった ${ }^{\text {i } 15) 。}$ 〈中央帯分布型〉の絵画の多くは近代以降に描かれていることから、 伝統的な構図法に則っていない絵が多いことが推測される。今回実 験で使用した絵画数が少ないため、今後絵画数を増やして検証する 必要があるが、構図法の活用と主題の認知しやすさには関連性があ ることが推測される。

\section{7. まとめ}

西洋絵画において建築や空間を構成するその他の要素の二次元的 認知の特徴を明らかにするために、対象絵画 39 点について、指摘法 実験を行った。分析結果の傾向を以下に述べる。

1）男性と女性の被験者の一部の指摘傾向に差異が見られた。具体的 には男性は通常背景や「地」と見なされる自然物や環境要素に着目し、 女性は人物に注目する傾向があった。

2）絵画を特徴づける要素の構成を明らかにするため、各絵画の指摘 率の低減傾向を 5 タイプに分類した。象徵性が高く、強い「図」と
なるような要素が一つないし数個あるもの（一点象徴型、複数象徴 型)、または飛びぬけて目立つものがなく、多様な要素によって構成 されるもの (分散型) などに分けられ、構図の配置との関係をドッ トマップ図に示した。絵画を特徴づける要素は絵画上の二次元空間 での奥行きの広がりにも関係することがわかった。

3）指摘された要素の構成を捉えるため、絵画毎に指摘要素を「建築」 「人物」「樹木」「空」「その他」の 5 つのカテゴリーに分類した。そ れらの指摘率を類似度としてクラスター分析を行い、4つの要素構成 型が得られ、その特徴を明らかにした。

4）絵画の中で指摘が集中する注目域の特徴を明らかにするため、要 素のカテゴリーは問わずに指摘要素の画面上の配置を類型化し、グ リッド解析図を作成した。この注目域分布型は6タイプに分けられた。 5）要素構成型と注目域分布型の相互関係をマトリックス表に表し、 それぞれの絵画の特徴を読み取ることができた。建築が「図」(主役) として認知される絵画は、中央帯型のように水平性の強い構図がよ く用いられていた。

6）指摘率は高いが指摘度は低い要素を「仮面の主題」と定義した。 仮面焦点は背景的な要素でありつつ「主役並に注目を集める図的な 地」であり、画面の周縁付近に位置することで、見る人の目を絵画 の主題に戻す役割があると考えられる。

7）注目域分布型の〈十字形型〉や〈三角形型〉は「仮面の主題」 がない絵の割合が高く、主題がわかりやすい構図と考えられる。一 方〈右下分布型〉や〈中央帯型〉は「仮面の主題」を持つ絵の割合 が高かった。20世紀以降に描かれた絵画は「仮面の主題」を持つ絵 の割合が高い傾向が見られた。

我々が西洋絵画を鑑賞するときに、その絵画を特徴づける印象深 い要素を、その種類や印象の強弱も含めて明らかにした。さらにそ の要素の配置構成との関係を読み取ることで、絵画の二次元的表現 において要素の配置構成上の意味や構図の空間的広がり・奥行きと の関係を示すことができた。

\section{謝辞}

本研究の集計・分析等にあたりご協力頂いた秋田工業高等専門学 校の鎌田光明先生、東京電機大学の渋谷沙季氏、キョン・ドゥヒョ ン氏、実験にご協力頂いた共立女子大学の高橋大輔先生に感謝申し 上げます。 


\section{注}

注 1) Paul Krutyはイリノイ大学の建築史の教授で、フランク・ロイド・ライ トのプレゼンテーション図面について論文を書いている。1

注 2）指摘法 : 実験の対象となる空間を体験させ、印象に残る要素を指摘して もらい、その位置を図上に示してもらう実験方法。3

注 3) HP DesignJet T790 ePrinter（最高解像度 : 2400 X 1200 dpi）を使用し、 出力した。

注 4）指摘法に関して、明確な被験者数について述べられたものはなく、過去 の研究を参考に、また男女の比率は等分に近くなるように努めて被験者 数を決定した。

注 5）実験の時間は、1 枚当たり最大 5 分とした。

注 6) 街路空間の指摘法実験の分析において著者は「主要エレメント」を指摘 率 $25 \%$ 以上の要素と定義したが、本研究対象の絵画においてはより多様 な主要素を捉えるため、主要素の定義は $25 \%$ の半分の $12.5 \%$ (被験者数 が 50 人で割り切れないため実際は $12 \%$ ）を採用した ${ }^{17)}$ 。

注 7）ゲシュタルト心理学の知見によれば、通常「空」は「地」と見なされる ことが多いが、西洋絵画において「空」は「雲」なども含み、季節感や 空間の雰囲気を表す重要な要素と考え、今回の実験ではカテゴリーのひ とつに採用した。

注 8）今回実験に使用した絵画は広範の時代やジャンル、様式にまたがってい るため、共通項のない指摘項目（「馬」、「サインポール」「「゙ート」など） も多く、それらを「その他」に分類した。

注 9）環境要素 : 偏在して環境を作っているが、個別に特定できない要素

注 10)高橋鷹志研究室は対象の持つ大きさと識別距離との関係を調査し、まと めている。見ている人から $2 \sim 10 \mathrm{~m}$ の範囲は「至近距離」、顔の表情がわ かる $10 〜 25 \mathrm{~m}$ の範囲は「近空間 I」、眉や目など顔のパーツが識別でき る $25 \sim 60 \mathrm{~m}$ の範囲は「近空間 II」、髪と顔が識別できる $60 \sim 500 \mathrm{~m}$ は 「中空間 I」、建物が立体的に見える $500 \mathrm{~m}$ から $1 \mathrm{~km}$ の範囲を「中空間 II」 人の存在が識別できる範囲の $1 \mathrm{~km}$ より遠くを「遠空間」と定義している。 本研究ではこの識別尺度を使って絵画の奥行きを推定した。18)

注 11)クラスター分析における類似度間の距離の算出方法は、ユーグリッド距 離による。(統計ソフト SPSS)

注 12)西洋絵画は黄金比を構図に取り入れている場合が多い。時代や画布の縦 横比によって、画布の四辺を黄金比 $1: 1.618$ で分割し、そこからの直線 を基準線としたり、一辺を黄金比矩形の長辺と見立てて、画面を分割し たりする手法などが使われたが、画面を $5 \times 5$ で割ったグリッドは黄金 比を使った基準線に近似しており、構図の傾向を捉える上で適当である と判断した ${ }^{19)}$ 。

注 13)グリッド解析法は、著者らの俳句から連想する心象風景の構成と心理評 価の研究において、イメージで捉えた風景の構成要素を数量的に分析す る手法として考案された。本研究では、これを絵画における構成要素の 構図を数量的に扱うため、グリッドの数を上述のように絵画にふさわし い数に調整し、応用した。

注 14)「仮面の主題」の「仮面」は「見せかけの」という意味で、主題でないに も関わらず、本来の絵画の主題（主役）を上回る印象的な要素と定義した。

注 15)『カラー版西洋美術史』 ${ }^{15)}$ は章ごとに時代様式を以下のように分類してい る。第 6 章「イタリア盛期ルネサンス美術、マニエリスム、北方ルネサ ンス美術」、第 7 章「バロック美術、ロココ美術」、第 8 章「近代 I：新古 典主義、ロマン主義、写実主義」、第 9 章「近代 II：印象主義、象徴主義、 後期印象主義」、第 10 章「現代 I」

注 16)19 世紀後半、特に印象派の発展と共に構図軽視の風潮が生まれた。その 後、何人かの後期印象派の画家たちは黄金比に基づく構図法の重要性を 再認識し、抽象画においても構図法は積極的に使われたが、一部に留まっ ている ${ }^{19)}$ 。

\section{参考文献}

1) Paul Kruty,“Graphic Depictions: The Evolutions of Marion Mahony's Architectural Renderings", David van Zanten ed., Marion Mahony Reconsidered, The University of Chicago Press, p.52, 2011

2）エルヴィン・パノフスキー：〈象徵形式〉としての遠近法、哲学書房、 1993

3）日本建築学会編 : 建築・都市計画のための調査・分析方法 改訂版 井 上書院，p. $140,2012.05$

4）黒田正巳：空間を描く遠近法，彰国社、1992.02

5）三輪祐仁、夏目欣昇、若山滋 : 西洋絵画の中の都市・建築空間一ルネサ
ンスから新古典主義一、日本建築学会計画系論文集、No. 613、pp.5964, 2007.03

6) 三輪祐仁、夏目欣昇、若山滋 : 17 世紀オランダ絵画の中の建築空間、日 本建築学会計画系論文集、No. 593, pp. 73-78，2005.07

7）福元彩、若山滋、夏目欣昇：ジョルジョ・デ・キリコの絵画と小説にお ける空間の記憶、日本建築学会大会学術講演梗概集、F-2、建築歴史・意 匠，pp. 785-786, 2009.07

8）福留吉絵、杉本俊多：17 世紀オランダ絵画に見られる透視図法に関す る研究、日本建築学会中国支部研究報告集、No. 31, “907-1”- “907-4”, 2008.03

9）坪山幸王、清水信友、佐藤信治：F．L．ライトの住宅における線透視図の 描かれ方と類型化について その 1、日本建築学会技術報告書、No． 9, pp. 187-191, 1999. 12

10）積田洋、濱本紳平 : 指摘エレメント構成型による都市空間の研究、日本 建築学会計画系論文集、No. 623, pp. 109-116，2008.01

11）積田洋、鈴木真理、木内愛 : グリッドマップ法による建築と外部空間の 大きさ認知の分析、日本建築学会計画系論文集、No. 659, pp.27-34, 2011.02

12）積田洋、竹内政裕、鈴木弘樹 : 俳句から連想寸る心象風景の構成と心理 的評価の研究、日本建築学会計画系論文集、No. 669, pp. 2093-2099, 2011. 11

13) Davies, P.J.E, et al., Janson's History of Art, Eighth edition, Prentice Hall, 2011

14) Kleiner, F. S., et al., Gardner's Art Through Ages, Twelfth edition, Wardsworth/Thomson Learning, 2005

15）高階秀爾監修：カラー版西洋美術史 増補新装版、美術出版社、2002.12

16）永井一正、木島俊介監修：高校美術 I/II 日本文教出版、2014.01

17）積田洋：心理量分析と指摘量分析による街路空間の「図」と「地」の分 析一街路の空間構造の研究（その 1) - 、日本建築学会計画論文集、No. 554, pp. 189-196, 2002.04

18）高橋研究室編：かたちのデータファイル、彰国社、1984.02

19）柳亮 : 新装版 黄金分割 西洋の比例、美術出版社、2012.05 


\title{
STUDY ON EVALUATION OF COGNITION ON THE TWO-DIMENSIONAL REPRESENTATION OF ARCHITECTURAL ELEMENTS IN WESTERN PAINTINGS
}

\author{
Kiwa MATSUSHITA* and Hiroshi TSUMITA** \\ * Assoc. Prof., Dept. of Architecture, School of Science and Technology for Future, TDU, M.Arch. \\ ** Prof., Dept. of Architecture, School of Science and Technology for Future, TDU, Dr. Eng.
}

Among the methods of two dimensional representation of architecture and space, such as plans and sections, the perspective drawing is one of the most effective presentation tools. Many techniques of the two-dimensional space representation, including the mathematical perspective drawings, were originally developed for the paintings. Despite of its differences from the actual sight, we recognize it as "accurate" representation of what we see. The two-dimensional representation of space includes not only the image of the stand-alone architecture, but also the way it appears in its surrounding environment and landscape. In this case, architecture, among the other elements, become one of the visual components, and they together represent "space." The objective of the research is to understand the cognition of the perspective images which represent three dimensional architecture and spaces, according to various frameworks, scale and subject. Thus, this paper specifically focuses on the Western paintings as a case of the spatial representation in broader frameworks. The Indication Method was used to quantitatively analyze the architectural and other elements in the paintings, their composition, and the impression they give to the viewers in order to deepen the understanding of the reception of the architectural representation.

As subjects of the research, 39 paintings were selected from the renowned art history text books between the periods of the Late Renaissance to mid Twentieth century. 50 architecture students (22 Males, 28 Females) were asked to note more than three elements which give strong impression for each painting. The summery of the research outcome is as follows:

1) The aggregation of the indications shows that the Human elements were most impressive elements among other major categories, such as Architecture, Tree, Sky and Others.

2) Males and females indicated notably different elements in some paintings. Men notably showed the tendency to indicate more environmental elements, such as "grass" or "lake", while women characteristically indicated the human elements, such as "Women and Child."

3) The downward trends of the indication rate for each painting are categorized into 5 types to find the composition of the elements which characterizes the paintings. These types are related to the sense of depth in two-dimensional space.

4) The indicated elements are sorted into five categories, Architecture, Human, Tree, Sky and the Others for each painting. Based on that data, the paintings are classified into four "Element Composition" types through the Cluster Analysis to see the types and characteristics of the indicated elements.

5) The locations of the indicated elements on the paintings are classified through the Cluster Analysis into six "Focus-zone" types, which are represented by gradation grids.

6) The relationship between the "Element Composition" and "Focus-zone" types are analyzed to capture the characteristics of paintings. The paintings, in which the architecture elements are considered to be "Figure (main character)" tend to use the horizontal composition.

7) The elements which have high indication rates but were not highly graded in the degree of impression were defined as "Disguised Motif." The disguised motif is the "Ground" elements which call for attention.

The research clarified the elements which characterized the paintings, including their categories and the degree of impression. The observation on their composition, moreover, showed the implication of the element structure and the spacial depth in the composition in two-dimensional representation in Western Paintings. 